\title{
Potential Role of Chemokines in Fracture Repair
}

\author{
Bouchra Edderkaoui ${ }^{1,2 *}$ \\ ${ }^{1}$ Musculoskeletal Disease Center, Loma Linda VA Health Care Systems, Loma Linda, CA, USA, ${ }^{2}$ Department of Medicine, \\ Loma Linda University, Loma Linda, CA, USA
}

Chemokines are a family of small cytokines that share a typical key structure that is stabilized by disulfide bonds between the cysteine residues at the $\mathrm{NH}_{2}$-terminal of the protein, and they are secreted by a great variety of cells in several different conditions. Their function is directly dependent on their interactions with their receptors. Chemokines are involved in cell maturation and differentiation, infection, autoimmunity, cancer, and, in general, in any situation where immune components are involved. However, their role in postfracture inflammation and fracture healing is not yet well established. In this article, we will discuss the response of chemokines to bone fracture and their potential roles in postfracture inflammation and healing based on data from our studies and from other previously published studies.

\section{OPEN ACCESS}

Edited by:

Annette Gilchrist,

Midwestern University, USA

Reviewed by:

Jawed Akhtar Siddiqui,

University of Nebraska Medical

Center, USA

Melissa Orlandin Premaor, Universidade Federal de Santa Maria,

Brazil

${ }^{*}$ Correspondence:

Bouchra Edderkaoui bouchra.edderkaoui@va.gov

Specialty section: This article was submitted to Bone Research, a section of the journal

Frontiers in Endocrinology

Received: 26 November 2016 Accepted: 15 February 2017

Published: 02 March 2017

Citation:

Edderkaoui B (2017) Potential Role of Chemokines in Fracture Repair.

Front. Endocrinol. 8:39. doi: 10.3389/fendo.2017.00039
Keywords: fractures, bone, inflammation, chemokines, cell migration, delay fracture repair

\section{INTRODUCTION}

Bone fracture healing is a complex progression of events that require a timely sequence of interactions between cells and their mediators. Both resident and infiltrating cells contribute to the three phases of fracture healing: inflammation (initial hematoma with subsequent infiltration of inflammatory cells), bone formation, and bone remodeling $(1,2)$.

Approximately 7.9 million fractures occur in the United States every year, and nearly 5-20\% exhibit delay or disruption in healing, resulting in significant morbidity and reduced productivity $(3,4)$. Thus, understanding the molecular mechanisms involved in postfracture inflammation and repair have the obvious potential to improve the quality and the time of fracture healing and translate into significant therapeutic benefit in both patient outcomes and reduced costs to society.

Delayed bone fracture healing and non-union fractures represent an important clinical problem, especially in patients with open fractures, patients with diabetes, and patients with multiple fractures who also suffer from posttraumatic systemic inflammation. However, the underlying biochemical and cellular mechanisms that become dysregulated during delayed union and non-union fracture repair remain controversial.

A key initial step in fracture repair is an inflammatory reaction involving immune cells that become activated immediately in response to tissue damage. Although much is known about the function of inflammatory cells as well as the other cells that migrate within the fracture in response to injury, little is known about the chemotactic and activation signals that influence this response. It is now well accepted that chemokines promote inflammation (5-7) and angiogenesis (8-10). In addition, chemokines are thought to play an important role in several aspects of bone metabolism including the recruitment of leukocytes and the formation of osteoclasts $(11,12)$. Therefore, they may contribute to the regulation of osteoneogenesis, by integrating inflammatory events and the reparative processes important in modulating fracture healing. 
This review will discuss chemokine expression in response to bone fracture and the potential role of these molecules in postfracture inflammation and healing.

\section{CHEMOKINES AND CHEMOKINE RECEPTORS}

Chemokines belong to a family of small cytokines. There are approximately 50 chemokines $(13,14)$ interacting with some 23 different receptors (15-19). They range in size from 8 to $20 \mathrm{kDa}$ and share a basic structure that is stabilized by disulfide bonds between cysteine residues. Based on the pattern of cysteine residues near the $\mathrm{N}$-terminus, chemokines can be divided into four subfamilies (20): (1) the CC subfamily, which includes beta chemokines, has cysteine residues adjacent to each other; (2) the CXC subfamily, which includes alpha chemokines, has cysteine residues that are separated by an intervening amino acid; (3) the $\mathrm{C}$ subfamily has one cysteine residue at the $\mathrm{N}$-terminus of the protein; and (4) the CX3C family, with only one representative, CX3CL1 (also known as neurotactin and fractalkine), in which the two cysteine residues are separated by three amino acids (21).

Chemokines are secreted by a great variety of cells such as mononuclear leukocytes (22-24), neutrophils (25-28), eosinophils (29), fibroblasts $(30,31)$, blood endothelial cells (32), and adipocytes $(33,34)$. They can be induced in several different conditions. The name "chemokine" is derived from the ability of chemokines to induce directed chemotaxis in nearby responsive cells. Some chemokines are considered pro-inflammatory and can be induced during an immune response to attract cells of the immune system to a site of infection, whereas others are considered homeostatic and are involved in controlling the migration of cells during normal physiological conditions (35, 36). Chemokines play roles in cell maturation and differentiation, infection, autoimmunity, cancer, and, in general, in any situation where immune components are involved. However, their role in postfracture inflammation and fracture healing is not yet well established.

Chemokine function is directly dependent on the interaction with chemokine receptors. Chemokine receptors are G proteinlinked transmembrane receptors located on the surfaces of target cells $(15,37)$. Chemokines bind their cognate $G$ protein-coupled receptors and trigger intracellular calcium fluxes. As a concentration of chemokines increases, calcium flux signaling continue to increase till it reaches a plateau, while cell migration increases with the increase of chemokine concentration but then returns to baseline. Typically, a moderate increase in chemokines' concentration leads to chemotactic migration, but a huge increase in the concentration of chemokines could halt cell migration (38). However, the signaling mechanisms that govern this phenomenon remain unclear.

There are 20 signaling chemokine receptors (37) and three non-signaling or scavenger receptors that serve to mediate chemokine-dependent signaling by binding, internalizing, and degrading chemokines $(39,40)$. Though similar to other seven-transmembrane receptors, signaling chemokine receptors share certain structural features, such as the highly conserved DRYLAIV amino acid sequence in the second intracellular loop (41), a feature that is absent in decoy receptors, indicating its implication in signaling. Several studies have shown that chemokine receptors are expressed on the surface of cells as both homo- and heterodimers (42-45), but the stability of the dimer is likely dependent on the presence of the ligand.

In a recent article, Muñoz et al. (46) have described the different types of dimerizations that occur between chemokine receptors, with ligands and receptors forming complexes in a dynamic equilibrium $(47,48)$, underscoring the complexity of chemokine activities. However, the lack of specific tools for stabilizing heterodimeric complexes, combined with the constantly changing equilibrium between receptor conformations, has complicated the studies of signaling functions of each dimer and limited our ability to modulate chemokine/receptor interaction using pharmacological approaches.

\section{CHANGES IN THE EXPRESSION OF CHEMOKINES IN RESPONSE TO FRACTURE AND THEIR POTENTIAL ROLE IN FRACTURE HEALING}

Although the function of the various cell types involved in postfracture inflammation is well established, the molecular mechanisms underlying the different phases of the bone repair process are still poorly understood. A thorough elucidation of how the spatial and temporal expression of chemokines and their receptors are modulated postfracture is ultimately essential to our understanding of the role of these chemokines in fracture repair.

Neutrophils are one of the most important cell types in the postfracture inflammation response. They are the first cell type to arrive at the fracture site in response to injury (49). They also express and produce chemokines that serve to attract further immune cells that ultimately participate in the healing process. A recent study, making use of a rat model in which a $5-\mathrm{mm}$ bone defect was created in the femur, has reported the detection of neutrophils, a few granulocytes, and a few monocytes at the site of the defect as early as $12 \mathrm{~h}$ postfracture (49). The study also found that the number of neutrophils peaked at 24-48 $\mathrm{h}$ postfracture, marking the beginning of the inflammatory stage in this particular model system. Eosinophils and basophile granulocytes were seen $24 \mathrm{~h}$ postsurgery. In addition, protein expression of the major pro-inflammatory cytokine IL-6 and three major neutrophil chemoattractants, CXCL1, CXCL2, and CXCL3 (49), showed an increase in concentration immediately after surgery and a re-equilibration to baseline before $24 \mathrm{~h}$ postsurgery.

Another chemokine reported to play a role in neutrophil migration is monocyte chemotactic protein (MCP) 1 , a member of CC chemokine family. MCP-1 has also been referred to as CCL2. It is a ligand for CCR2 but can also bind the Duffy antigen receptor for chemokines (DARC) (50). CCL2 is one of the first and most highly expressed chemokines in response to fracture in both animal models (51-54) and human fractures (55) (Table 1). 
TABLE 1 | Chemokines that are upregulated during acute phase of fracture healing.

\begin{tabular}{|c|c|c|c|}
\hline $\begin{array}{l}\text { Chemokine } \\
\text { name }\end{array}$ & $\begin{array}{l}\text { Specific } \\
\text { chemokine } \\
\text { receptors }\end{array}$ & $\begin{array}{l}\text { Type of fracture (fracture } \\
\text { model bone animal model) }\end{array}$ & Reference \\
\hline $\begin{array}{l}\text { CCL2 } \\
\text { [monocyte } \\
\text { chemotactic } \\
\text { protein } \\
\text { (MCP) 1] }\end{array}$ & CCR2 & $\begin{array}{l}\text { Stress fracture (axial } \\
\text { loading-ulna-rat) } \\
\text { Single fracture (3-point } \\
\text { bending - tibia - mouse) } \\
\text { Not stabilized single fracture } \\
\text { (3-point bending-tibia-mouse) } \\
\text { Single fracture (rib - mouse) } \\
\text { Single fracture (human) }{ }^{a}\end{array}$ & $\begin{array}{l}\text { Wu et al. (51) } \\
\text { Rundle et al. } \\
\text { (52) } \\
\text { Xing et al. (54) } \\
\text { Ishikawa et al. } \\
\text { (53) } \\
\text { Hoff et al. (55) }\end{array}$ \\
\hline $\begin{array}{l}\text { CCL3 } \\
\text { [macrophage } \\
\text { inflammatory } \\
\text { protein } 1 \text { alpha } \\
\text { (MIP-1a)] }\end{array}$ & $\begin{array}{l}\text { CCR1, } \\
\text { CCR5 }\end{array}$ & $\begin{array}{l}\text { Single fracture ( } 3 \text {-point } \\
\text { bending - tibia-mouse) Single } \\
\text { fracture (human) })^{\mathrm{a}}\end{array}$ & $\begin{array}{l}\text { Rundle et al. } \\
\text { (52), Hoff } \\
\text { et al. (55) }\end{array}$ \\
\hline $\begin{array}{l}\text { CCL4 } \\
\text { [macrophage } \\
\text { inflammatory } \\
\text { protein } 1 \text { beta } \\
\text { (MIP-1b)] }\end{array}$ & $\begin{array}{l}\text { CCR1, } \\
\text { CCR4, } \\
\text { CCR5 }\end{array}$ & Single fracture (femur-human) ${ }^{a}$ & Hoff et al. (55) \\
\hline $\begin{array}{l}\text { CCL5 } \\
\text { (Regulated } \\
\text { upon Activation, } \\
\text { Normally } \\
\text { T-Expressed, } \\
\text { and presumably } \\
\text { Secreted) }\end{array}$ & $\begin{array}{l}\text { CCR1, } \\
\text { CCR3, } \\
\text { CCR5 }\end{array}$ & Single fracture (femur-human) ${ }^{a}$ & Hoff et al. (55) \\
\hline CCL7 (MCP-3) & $\begin{array}{l}\text { CCR1, } \\
\text { CCR2, } \\
\text { CCR3 }\end{array}$ & $\begin{array}{l}\text { Not stabilized single fracture } \\
\text { (3-point bending-tibia- } \\
\text { mouse). Single fracture } \\
\text { (Femur-human) }^{\text {a }}\end{array}$ & $\begin{array}{l}\text { Xing et al. } \\
\text { (54), Hoff } \\
\text { et al. (55) }\end{array}$ \\
\hline CCL8 (MCP-2) & $\begin{array}{l}\text { CCR1, } \\
\text { CCR2, } \\
\text { CCR5 }\end{array}$ & $\begin{array}{l}\text { Not stabilized single fracture } \\
\text { (3-point bending - tibia-mouse) }\end{array}$ & Xing et al. (54) \\
\hline CCL11 (Eotaxin) & $\begin{array}{l}\text { CCR3, } \\
\text { CCR2, } \\
\text { CCR5 }\end{array}$ & Single fracture (femur - human)a & Hoff et al. (55) \\
\hline $\begin{array}{l}\text { CXCL1, CXCL2, } \\
\text { CXCL3 }\end{array}$ & CXCR2 & $\begin{array}{l}\text { Segmental defect ( } 5 \mathrm{~mm} \text { bone } \\
\text { defect-femur-rat) }\end{array}$ & $\begin{array}{l}\text { Förster } \\
\text { et al (49) }\end{array}$ \\
\hline $\begin{array}{l}\text { CXCL10 (IFN- } \\
\gamma \text {-inducible } \\
\text { protein 10) }\end{array}$ & CXCR3 & Single fracture (femur - human)a & Hoff et al. (55) \\
\hline $\begin{array}{l}\text { CXCL8 } \\
\text { (interleukin-8) }\end{array}$ & $\begin{array}{l}\text { CXCR1, } \\
\text { CXCR2, } \\
\text { IL8R }\end{array}$ & Single fracture (femur-human) ${ }^{a}$ & Hoff et al. (55) \\
\hline $\begin{array}{l}\text { CXCL12 } \\
\text { (stroma cell- } \\
\text { derived factor } 1 \text { ) }\end{array}$ & $\begin{array}{l}\text { CXCR4 } \\
\text { CXCR7 }\end{array}$ & $\begin{array}{l}\text { Segmental defect and live bone } \\
\text { graft (mouse) }\end{array}$ & $\begin{array}{l}\text { Kitaori et al. } \\
(90)\end{array}$ \\
\hline
\end{tabular}

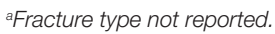

CCL2 is involved in regulating neutrophil migration (56), angiogenesis, and macrophage infiltration in several inflammatory processes $(57,58)$ as well as regulating the migration of CD4+ T regulatory cells (59). Furthermore, CCL2 has been shown to be expressed at the periosteum around the fracture site during fracture healing (53), suggesting that CCL2 is involved in both postfracture inflammation and bone remodeling.

It has been previously reported that tumor necrosis factor alpha (TNF $\alpha$ ) enhances neutrophil recruitment in early postfracture inflammation and promotes the recruitment of monocytes by stimulating CCL2 production (7). Furthermore, depletion of neutrophils by Ly6G neutralizing antibody or inhibition of the CCL2 chemokine receptor CCR2 in a murine tibial fracture model resulted in significantly impaired fracture healing (7), while early treatment with TNF $\alpha$ increased neutrophil infiltration to the fracture area, as well as the expression of CCL2, when compared to untreated fractures (7). In another study with open tibial fracture, it has been reported that local treatment with low concentrations of TNF $\alpha$ enhanced fracture repair (60). This illustrates the importance of postfracture inflammation and especially the roles of TNF $\alpha$ and CCL2 in fracture healing. Moreover, the expression level of $\mathrm{CCl} 2$ was increased in patients with systemic skeletal disease such as osteoporotic patients (61), and the serum level of CCL2 was greater up to 4 weeks postsurgery in patients with type 2 diabetes compared to healthy patients (62). In both cases, patients suffered from fragility fractures, and the delay in fracture healing was obvious in type 2 diabetic patients, which suggested that increased level of CCL2 in the serum is one of the leading causes to impaired fracture healing in diabetic patients.

In an anabolic regimen, intermittent treatment with parathyroid hormone (PTH) caused MCP-1 expression to increase over time, eventually reaching 200-fold higher levels after 14 days of treatment. This in turn was accompanied by an increase in bone volume in the PTH-treated animals, compared to untreated control animals (63). Together, these data suggest that in addition to its role in chemotaxis of monocytes and neutrophils and osteolysis (64) during inflammatory bone remodeling, CCL2 might also be involved in bone formation during skeletal repair. However, this remains to be tested.

Macrophage inflammatory protein 1 alpha, also known as CCL3, binds to CCR1 and CCR5 (Table 1), which are receptors that mediate CCL3 chemotactic functions. CCL3 is produced by macrophages, natural killer cells, fibroblasts, and mast cells. Its expression in fracture callus was found to be upregulated during the first 3 days postfracture in both animal (52) and human models (55). In models with systemic inflammation, such as a rat diabetic model, increased levels of CCL3 in serum was also associated with delayed fracture healing, indicating the importance of a well-controlled inflammation on the overall process of fracture healing (65). In contrast to CCL2, the role of CCL3 in postfracture healing has not been well investigated.

Macrophage inflammatory protein 1 beta, also known as CCL4, binds the CCR1, CCR4, and CCR5 receptors (Table 1). CCL4 is secreted by major leukocytes such as T cells, B cells, and monocytes (66), and its expression was observed to be upregulated in fracture hematoma within 3 days postfracture, in parallel with an increase in the number of monocytes (55). Chondrocytes, in particular hypertrophic chondrocytes, have been identified as another source of CCL4. Expression of CCL4 by these cells has been shown to be dependent on TNF $\alpha$ in diabetic fractures (67). This suggests a role for TNF $\alpha$ and CCL4 in the loss of cartilage that is observed during the process of diabetic fracture healing. 
However, Lin et al. (68) have reported a differential expression of CCL4 in mesenchymal stem cells (MSCs) treated with highmobility group box. These data together illustrate a complex role of CCL4 in fracture healing that still needs to be investigated.

The chemokine regulated upon Activation, Normally T-Expressed, and presumably secreted, also called CCL5, binds CCR1, CCR3, and CCR5 (Table 1) and is expressed in T lymphocytes. CCL5 promotes the recruitment and activation of inflammatory cells such as monocytes (69), lymphocytes (70), mast cells (71), and eosinophils (72). In the case of infection by pathogens, it is known to play a protective effect, through its interaction with CCR5 and the downstream ERK1/ERK2 and AKT signaling pathways. In a study of human fractures, CCL5 levels increased both at the site of the fracture hematoma and in the surrounding bone marrow (55). The magnitude of increase was greater in the fracture hematoma compared to surrounding bone marrow, an effect that can be likely explained by increased infiltration of T cells.

Monocyte chemotactic protein 3, also known as CCL7, binds the CCR1, CCR2, and CCR3 receptors. CCL7 is another mediator of pro-inflammatory pathways by virtue of its ability to activate leukocytes $(73,74)$. Previous studies have identified CCL7 as a homing factor for MSCs (75). In a mouse model, mRNA levels of CCL7 increased as early as 1 day postfracture (53), peaked at 2 days postfracture $(53,54)$, with a subsequent decline beginning at 3 days postfracture, but combined trauma model resulted in a significant increase in the level of CCL7 in plasma as early as $6 \mathrm{~h}$ postfracture that lasted up to 3 days postinjury compared to control non-injured animals (76).

Monocyte chemotactic protein 2, also known as CCL8, binds to the CCR1, CCR2, and CCR5 receptors. CCL8 attracts leukocytes and possesses various immunomodulating functions. Like other CC family chemokines, it influences mononuclear cell types (77). CCL8 was found to be upregulated (Table 1) during the first 7 days postfracture (54).

Eotaxin, also known as CCL11, binds the CCR2, CCR3, and CCR5 receptors, thus affecting the migration of eosinophils that express the CCR3 receptor, as well as monocytes that express both CCR2 and CCR5 (78). It has been reported that pretreatment of human monocytes with eotaxin reduces the binding of CCL2, the selective ligand for the CCR2, to monocytes (78) as well as the binding of CCL5 and CCL4 to CCR5. In previous studies (78), pretreatment of human monocytes with eotaxin triggered CCR5 activity at low concentrations of the ligand, while CCR 2 was not activated by doses as high as $1 \mu \mathrm{M}$ eotaxin, which suggested that eotaxin is a CCR5 agonist and a CCR2 antagonist (78). In fracture calluses, CCL11 was found to be upregulated within 3 days postfracture (Table 1) in human models (55).

IFN- $\boldsymbol{\gamma}$-inducible protein 10 (IP10), also called CXCL10, binds to CXCR3 and is secreted from a variety of cells, including monocytes, endothelial cells, and fibroblasts, in response to interferon (79). CXCL10 inhibits bone marrow colony formation (80). It is a chemoattractant for human monocytes and T cells and promotes $\mathrm{T}$ cell adhesion to endothelia (80). Its expression is upregulated by both interferons and other inflammatory stimuli. It was found to be upregulated in fracture surrounding bone marrow in humans (Table 1), in parallel with an increase in the level of IFN- $\gamma$ and TNF $\alpha$ and an increase in the number of $\mathrm{CD} 3+$ and $\mathrm{CD} 3+\mathrm{CD} 4+\mathrm{T}$ cells in the surrounding bone marrow (55). Serum level of CXCL10 was found to be elevated in fracture patients with type 2 diabetes mellitus compared to patients with diabetes without fracture and normal patient with fracture (81). However, what role IP10 plays during fracture healing remains to be determined.

Interleukin-8, or CXCL8, binds the CXCR1, CXCR2, and IL-8R receptors $(82,83)$. IL-8 induces migration of hematopoietic progenitor cells through stimulation of the $\beta 2$-integrin LFA- 1 pathway (84). IL-8 levels have also been shown to be upregulated to a greater degree in fracture hematoma than in the surrounding bone marrow (Table 1), in parallel with an increase in the number of monocytes, granulocytes, and CD34+ HSCs (55). This suggests a role for IL- 8 in HSC infiltration in response to bone injury.

Stroma cell-derived factor 1 , also called CXCL12, binds the CXCR4 and CXCR7 receptors on the cell surface of responsive cells $(85,86)$. Local expression of CXCL12 has been shown to attract hematopoietic and endothelial progenitors to ischemic sites $(87,88)$. It is also expressed in bone marrow stroma cells (89) and has been reported to be upregulated at the endosteal surface around the injured bone from 7 to 14 days postsurgery (89). However, in other studies, CXCL12 levels have been reported to peak at different time points postfracture. For example, in a murine segmental bone graft model, CXCL12 levels were increased at the periosteum of the live bone graft from the first day of surgery, and its level continued increasing with time (90). In another murine model of fracture healing, CXCL12 expression was found in the fracture callus of hypertrophic cartilage and in immature cartilage near the pre-existing cortical bone (91). One explanation for the discrepancy in the time when CXCL12 expression peaks after fracture may be due to the specific nature of the injury. In some injuries, oxygen tension may change rapidly and since CXCL12 is reportedly regulated by a hypoxia-specific transcription factor, hypoxia-inducible factor 1 , the expression of CXCL12 may increase rapidly after the blood supply is stopped in those models (92).

CXCL12 is well accepted as a major chemokine that plays a critical role in fracture repair. It is involved in fracture repair through possibly two mechanisms. One is by recruiting endothelial progenitor cells, thus contributing to increased angiogenesis (87), a key phase in fracture repair. The other involves enhancing the homing of osteoblastic progenitors to promote new bone formation (93).

In the presence of inflammation, endothelial cells are stimulated to increase the surface expression of adhesion molecules, such as selectins, as well as integrin ligands such as vascular cell adhesion molecule-1 and intercellular adhesion molecule-1. Subsequently, chemokines produced at the site of injury bind and activate chemokine receptors that are present at high concentrations on the surface of endothelial cells $(94,95)$. Once activated, chemokine receptors permit the transcytosis of chemokines from one side to other side of vascular endothelial membrane, resulting in chemotaxis. The level of chemokines and the time of their bioavailability around the injured bone and in blood circulation 
are key factors that influence cell recruitment to the injured bone for subsequent fracture repair.

\section{FUNCTIONAL STUDIES USING KNOCKOUT MICE}

Animal models involving targeted knockout (KO) of selective chemokines and their receptors have been used to evaluate the role of chemokines in fracture repair process. Studies involving KO of DARC (52), CCL2/CCR2 (53), and CXCL12/CXCR4 (90) have illustrated a key role of chemokines in fracture healing. However, the role for a number of other chemokines such as CCL3 (96), CCL5 $(97,98)$, and CCL7 (75), found to be upregulated during the early phase of fracture healing and function as chemoattractants for MSCs, remains to be elucidated.

Postfracture inflammation has been evaluated in our mouse model using standard closed femoral fracture at the midshaft (52). The mRNA expression levels of IL-1 $\beta$, IL-6, tumor necrosis factor, and CCL2, which binds to DARC and CCR2, were increased 1 day postfracture. However, the magnitude of increase was lower in DARC-KO fracture calluses, consistent with a reduced inflammatory response. Accordingly, the number of macrophages was significantly reduced around the fractures in DARC-KO mice compared to wild type mice. This was associated with greater collagen (COL) II expression at 3 days and COL-X at 7 days postfracture, compared to wild-type mice, suggesting that lack of DARC expression in DARC-KO mice led to an early or premature fracture cartilage formation and differentiation. However, by 21 days postfracture, histological analysis did not show any difference in fracture healing between DARC-KO and wild-type mice. This may have been the result of a reduction in the recruitment of osteoclast precursors to the fracture callus in DARC-KO mice, which in turn has increased the time required for the transition from cartilage callus to bone.

By using a rib fracture model and graft exchanges, Ishikawa et al. (53) have reported delayed fracture healing at 21 days postfracture in both CCL2-KO and CCR2-KO mice and that blockade of the CCR2 receptor only in the early phase of healing caused delayed fracture healing in wild-type mice. The discrepancy between our model and the CCL2-KO model could be due to CCL2 expression not being sufficiently reduced in DARC-KO mice so as to cause a delay in fracture healing (52). Furthermore, the finding that CCL2 exhibits a significant chemotactic effect on neutrophils (56) and MSCs (53) but has no effect on osteogenesis or chondrogenesis (53) suggests that the effect of CCL2 on fracture healing occurs via early neutrophil recruitment and MSC recruitment to the fracture site for subsequent bone formation.

Other studies have also reported the importance of MSC recruitment in fracture healing (99). By using heterozygous CXCL12+/- and CXCR4+/- mice, Kitaori et al. (90) have demonstrated that CXCL12 recruits MSCs to the injured bone postfracture for subsequent bone formation. Furthermore, it has been reported that following fracture, a CXCL12- and BMP2-positive perivascular cell population is recruited along the endosteum. This is then followed by an increase in BMP2 levels that leads to downregulation of CXCL12, a step that is essential for the differentiation of CXCL12 and BMP2+ cells during osteogenesis. Moreover, CXCL12 has been shown to regulate BMP-2-stimulated osteogenic differentiation (100), while the CXCR4 receptor is involved in regulating osteoblast development in postnatal bone (101). Therefore, we conclude that CXCL12 signaling may have roles in fracture healing that extend beyond cell recruitment, including direct effects on MSC proliferation and differentiation into cells of the chondrogenic and osteogenic lineages.

\section{CONCLUSION}

In conclusion, various chemokines are involved in postfracture inflammation and healing, and their induction and involvement in the whole process are dose, site, and time dependent. Two chemokines have been investigated extensively for their role in fracture healing: CCL2 and CXCL12. CCL2 is involved in neutrophil recruitment, which is an early stage of fracture healing and in MSC infiltration for subsequent fracture repair. The importance of CCL2 and its specific receptor CCR2 in the progress of fracture healing have been demonstrated in mouse models (KO mice) that lack CCL2 or CCR2 expression and which showed delayed healing. However, an increase in CCL2 levels in plasma postfracture has been associated with a likelihood of delayed fracture healing. CXCL12, which is expressed in bone marrow and perivascular stroma cells, is crucial for the recruitment of MSC to the injured bone postfracture, a necessary step for subsequent bone formation. On the basis of the above findings, we proposed a model (Figure 1) where fracture induces secretion of TNF $\alpha$ and Il-6, as well as CXCLs that attract neutrophils. Neutrophils would be expected to induce monocyte chemotaxis

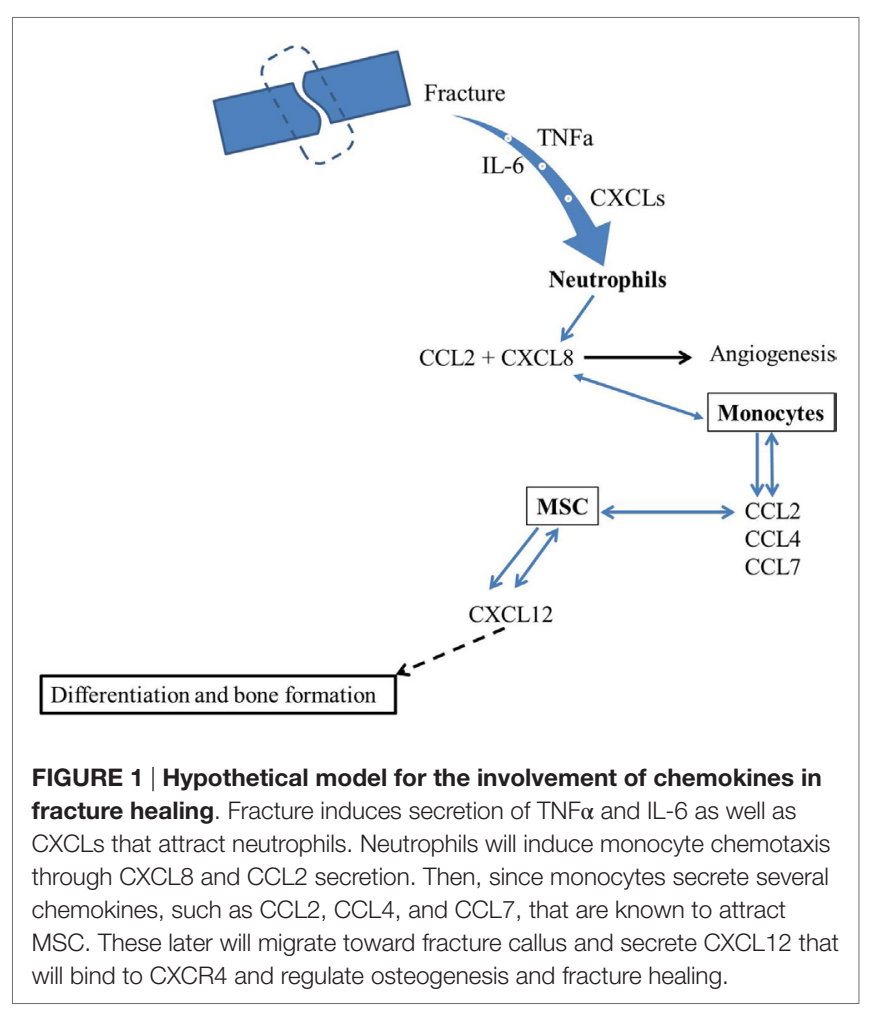


via stimulation of CCL2 secretion. Then, once monocytes secrete several chemokines, such as CCL2, CCL4, and CCL7, known to attract MSC, these cells will be induced to migrate toward fracture callus and secrete CXCL12. CXCL12 will in turn bind to CXCR4 and regulate BMP2 effects on osteogenesis and fracture healing. Currently, no published study has investigated the involvement of CCL4 and CCL7 in fracture healing. Thus, the issue of whether other chemokines are involved in fracture healing and how they interact with each other in the fracture healing process remains to be investigated. A comprehensive understanding of the role of chemokines in the fracture healing process could lead to development of chemokine-based therapies to promote healing of non-union fractures.

\section{REFERENCES}

1. Cruess RL, Dumont J. Fracture healing. Can J Surg (1975) 18:403-13.

2. Simmons DJ. Fracture healing perspectives. Clin Orthop Relat Res (1985) 200:100-13.

3. Einhorn TA, Lane JM. Significant advances have been made in the way surgeons treat fractures. Clin Orthop Relat Res (1998) 355(Suppl):S2-3. doi:10.1097/00003086-199810001-00001

4. Zeckey C, Mommsen P, Andruszkow H, Macke C, Frink M, Stübig T, et al. The aseptic femoral and tibial shaft non-union in healthy patients - an analysis of the health-related quality of life and the socioeconomic outcome. Open Orthop J (2011) 5:193-7. doi:10.2174/1874325001105010193

5. Speyer CL, Ward PA. Role of endothelial chemokines and their receptors during inflammation. J Invest Surg (2011) 24:18-27. doi:10.3109/08941939 .2010 .521232

6. Mai J, Virtue A, Shen J, Wang H, Yang XF. An evolving new paradigm: endothelial cells-conditional innate immune cells. J Hematol Oncol (2013) 6:61. doi:10.1186/1756-8722-6-61

7. Chan JK, Glass GE, Ersek A, Freidin A, Williams GA, Gowers K, et al. Lowdose TNF augments fracture healing in normal and osteoporotic bone by up-regulating the innate immune response. EMBO Mol Med (2015) 7:547-61. doi:10.15252/emmm.201404487

8. Xu X, Huang P, Yang B, Wang X, Xia J. Roles of CXCL5 on migration and invasion of liver cancer cells. J Transl Med (2014) 12:193. doi:10.1186/1479-5876-12-193

9. Stamatovic SM, Keep RF, Mostarica-Stojkovic M, Andjelkovic AV. CCL2 regulates angiogenesis via activation of Ets-1 transcription factor. J Immunol (2006) 177:2651-61. doi:10.4049/jimmunol.177.4.2651

10. Scapini P, Morini M, Tecchio C, Minghelli S, Di Carlo E, Tanghetti E, et al. CXCL1/macrophage inflammatory protein-2-induced angiogenesis in vivo is mediated by neutrophil-derived vascular endothelial growth factor-A. J Immunol (2004) 172:5034-40. doi:10.4049/jimmunol.172.8.5034

11. Dapunt U, Maurer S, Giese T, Gaida MM, Hansch GM. The macrophage inflammatory proteins MIP1 $\alpha$ (CCL3) and MIP2 $\alpha$ (CXCL2) in implantassociated osteomyelitis: linking inflammation to bone degradation. Mediators Inflamm (2014) 2014:728619. doi:10.1155/2014/728619

12. Goto Y, Aoyama M, Sekiya T, Kakita H, Waguri-Nagaya Y, Miyazawa K, et al. CXCR4+ CD45- cells are niche forming for osteoclastogenesis via the SDF-1, CXCL7, and CX3CL1 signaling pathways in bone marrow. Stem Cells (2016) 34:2733-43. doi:10.1002/stem. 2440

13. Rot A, von Andrian UH. Chemokines in innate and adaptive host defense: basic chemokinese grammar for immune cells. Annu Rev Immunol (2004) 22:891-928. doi:10.1146/annurev.immunol.22.012703.104543

14. Murphy PM. International union of pharmacology. Update on chemokine receptor nomenclature. Pharmacol Rev (2002) 54:227-9. doi:10.1124/ pr.54.2.227

15. Murphy PM, Baggiolini M, Charo IF, Hébert CA, Horuk R, Matsushima K, et al. International union of pharmacology. XXII. Nomenclature for chemokine receptors. Pharmacol Rev (2000) 52:145-76.

\section{AUTHOR CONTRIBUTIONS}

$\mathrm{BE}$ prepared the manuscript and collected the data.

\section{ACKNOWLEDGMENTS}

All work was performed at the facilities provided by the Veterans Administration in Loma Linda, CA, USA. The author thanks Dr. Mohan S and Dr. Rasmussen C, for their help in editing this manuscript. Our experiments were supported by the US Department of Defense (DOD), Award number W81XWH-10-1-0952. The content is solely the responsibility of the authors and does not necessarily represent the official views of the DOD.

16. Gosling J, Dairaghi DJ, Wang Y, Hanley M, Talbot D, Miao Z, et al. Cutting edge: identification of a novel chemokine receptor that binds dendritic celland T cell-active chemokines including ELC, SLC, and TECK. J Immunol (2000) 164:2851-6. doi:10.4049/jimmunol.164.6.2851

17. Chaudhuri A, Polyakova J, Zbrzezna V, Williams K, Gulati S, Pogo AO. Cloning of glycoprotein D cDNA, which encodes the major subunit of the Duffy blood group system and the receptor for the Plasmodium vivax malaria parasite. Proc Natl Acad Sci U S A (1993) 90:10793-7. doi:10.1073/ pnas.90.22.10793

18. Nibbs RJ, Gilchrist DS, King V, Ferra A, Forrow S, Hunter KD, et al. The atypical chemokine receptor D6 suppresses the development of chemically induced skin tumors. J Clin Invest (2007) 117:1884-92. doi:10.1172/JCI30068

19. Nibbs RJ, Wylie SM, Yang J, Landau NR, Graham GJ. Cloning and characterization of a novel promiscuous human beta-chemokine receptor D6. J Biol Chem (1997) 272:32078-83. doi:10.1074/jbc.272.51.32078

20. Zlotnik A, Yoshie O. Chemokines: a new classification system and their role in immunity. Immunity (2000) 12:121-7. doi:10.1016/S1074-7613(00) 80165-X

21. Pan Y, Lloyd C, Zhou H, Dolich S, Deeds J, Gonzalo JA, et al. Neurotactin, a membrane-anchored chemokine upregulated in brain inflammation. Nature (1997) 387:611-7 Erratum in Nature (1997) 389(6646):100. doi:10.1038/42491

22. Lord PC, Wilmoth LM, Mizel SB, McCall CE. Expression of interleukin-1 alpha and beta genes by human blood polymorphonuclear leukocytes. J Clin Invest (1991) 87:1312-21. doi:10.1172/JCI115134

23. Wolpe SD, Sherry B, Juers D, Davatelis G, Yurt RW, Cerami A. Identification and characterization of macrophage inflammatory protein 2. Proc Natl Acad Sci U S A (1989) 86:612-6. doi:10.1073/pnas.86.2.612

24. Sallusto F, Schaerli P, Loetscher P, Schaniel C, Lenig D, Mackay CR, et al. Rapid and coordinated switch in chemokine receptor expression during dendritic cell maturation. Eur J Immunol (1998) 28:2760-9. doi:10.1002/ (SICI)1521-4141(199809)28:09<2760::AID-IMMU2760>3.0.CO;2-N

25. Bazzoni F, Cassatella MA, Rossi F, Ceska M, Dewald B, Baggiolini M. Phagocytosing neutrophils produce and release high amounts of the neutrophil-activating peptide 1/interleukin 8. J Exp Med (1991) 173:771-4. doi:10.1084/jem.173.3.771

26. Strieter RM, Kasahara K, Allen R, Showell HJ, Standiford TJ, Kunkel SL. Human neutrophils exhibit disparate chemotactic factor gene expression. Biochem Biophys Res Commun (1990) 173:725-30. doi:10.1016/ S0006-291X(05)80095-6

27. Kasama T, Strieter RM, Lukacs NW, Burdick MD, Kunkel SL. Regulation of neutrophil-derived chemokine expression by IL-10. J Immunol (1994) 152:3559-69.

28. Xing Z, Jordana M, Kirpalani H, Driscoll KE, Schall TJ, Gauldie J. Cytokine expression by neutrophils and macrophages in vivo: endotoxin induces tumor necrosis factor-a, macrophage inflammatory protein-2, interleukin-1b, and interleukin- 6 but not RANTES or transforming growth factor-b1 mRNA expression in acute lung inflammation. Am J Respir Cell Mol Biol (1994) 10:148-53. Erratum in: Am J Respir Cell Mol Biol (1994) 10:following 346. 
29. Ponath PD, Qin S, Ringler DJ, Clark-Lewis I, Wang J, Kassam N, et al. Cloning of the human eosinophil chemoattractant, eotaxin. Expression, receptor binding, and functional properties suggest a mechanism for the selective recruitment of eosinophils. J Clin Invest (1996) 197:604-12. doi:10.1172/ JCI1 18456

30. Diny NL, Hou X, Barin JG, Chen G, Talor MV, Schaub J, et al. Macrophages and cardiac fibroblasts are the main producers of eotaxins and regulate eosinophil trafficking to the heart. Eur J Immunol (2016) 46:2749-60. doi:10.1002/ eji.201646557

31. Distler O, Pap T, Kowal-Bielecka O, Meyringer R, Guiducci S, Landthaler $\mathrm{M}$, et al. Overexpression of monocyte chemoattractant protein 1 in systemic sclerosis: role of platelet-derived growth factor and effects on monocyte chemotaxis and collagen synthesis. Arthritis Rheum (2001) 44:2665-78. doi:10.1002/1529-0131(200111)44:11<2665::AID-ART446>3.0.CO;2-S

32. Campbell JJ, Haraldsen G, Pan J, Rottman J, Qin S, Ponath P, et al. The chemokine receptor CCR4 in vascular recognition by cutaneous but not intestinal memory T cells. Nature (1999) 400:776-80. doi:10.1038/23495

33. Sartipy P, Loskutoff DJ. Monocyte chemoattractant protein 1 in obesity and insulin resistance. Proc Natl Acad Sci U S A (2003) 100:7265-70. doi:10.1073/ pnas. 1133870100

34. Kanda H, Tateya S, Tamori Y, Kotani K, Hiasa K, Kitazawa R, et al. MCP-1 contributes to macrophage infiltration into adipose tissue, insulin resistance, and hepatic steatosis in obesity. J Clin Invest (2006) 116:1494-505. doi:10.1172/JCI26498

35. Clark-Lewis I, Kim KS, Rajarathnam K, Gong JH, Dewald B, Moser B, et al. Structure-activity relationships of chemokines. J Leukoc Biol (1995) 57:703-11.

36. Zlotnik A, Morales J, Hedrick JA. Recent advances in chemokines and chemokine receptors. Crit Rev Immunol (1999) 19:1-47. doi:10.1615/ CritRevImmunol.v19.i1.10

37. Griffith JW, Sokol CL, Luster AD. Chemokines and chemokine receptors: positioning cells for host defense and immunity. Annu Rev Immunol (2014) 32:659-702. doi:10.1146/annurev-immunol-032713-120145

38. Roy I, Getschman AE, Volkman BF, Dwinell MB. Exploiting agonist biased signaling of chemokines to target cancer. Mol Carcinog (2017) 56:804-13. doi: $10.1002 / \mathrm{mc} .22571$

39. Graham GJ, McKimmie CS. Chemokine scavenging by D6: a movable feast. Trends Immunol (2006) 27:381-6. doi:10.1016/j.it.2006.06.006

40. Nibbs R, Graham G, Rot A. Chemokines on the move: control by the chemokine interceptors Duffy blood group antigen and D6. Semin Immunol (2003) 15:287-94. doi:10.1016/j.smim.2003.08.006

41. Murphy PM. The molecular biology of leukocyte chemoattractant receptors. Annu Rev Immunol (1994) 12:593-633. doi:10.1146/annurev. iy.12.040194.003113

42. Hamatake M, Aoki T, Futahashi Y, Urano E, Yamamoto N, Komano J. Ligandindependent higher-order multimerization of CXCR4, a G-protein-coupled chemokine receptor involved in targeted metastasis. Cancer Sci (2009) 100:95-102. doi:10.1111/j.1349-7006.2008.00997.x

43. Hernanz-Falcon P, Rodriguez-Frade JM, Serrano A, Juan D, del Sol A, Soriano SF, et al. Identification of amino acid residues crucial for chemokine receptor dimerization. Nat Immunol (2004) 5:216-23. doi:10.1038/ ni1027

44. Percherancier Y, Berchiche YA, Slight I, Volkmer-Engert R, Tamamura H, Fujii N, et al. Bioluminescence resonance energy transfer reveals ligandinduced conformational changes in CXCR4 homo- and heterodimers. J Biol Chem (2005) 280:9895-903. doi:10.1074/jbc.M411151200

45. Rodriguez-Frade JM, Vila-Coro AJ, de Ana AM, Albar JP, Martinez AC, Mellado M. The chemokine monocyte chemoattractant protein-1 induces functional responses through dimerization of its receptor CCR2. Proc Natl Acad Sci U S A (1999) 96:3628-33. doi:10.1073/pnas.96.7.3628

46. Muñoz LM, Holgado BL, Martínez-A C, Rodríguez-Frade JM, Mellado M. Chemokine receptor oligomerization: a further step toward chemokine function. Immunol Lett (2012) 145:23-9. doi:10.1016/j.imlet.2012.04.012

47. Muñoz LM, Barroso R, Dyrhaug SY, Navarro G, Lucas P, Soriano SF, et al. CCR5/CD4/CXCR4 oligomerization prevents HIV-1 gp120IIIB binding to the cell surface. Proc Natl Acad Sci U S A (2014) 111(19):E1960-9. doi:10.1073/pnas.1322887111

48. Gilliland CT, Salanga CL, Kawamura T, Trejo J, Handel TM. The chemokine receptor CCR1 is constitutively active, which leads to $\mathrm{G}$ protein-independent, $\beta$-arrestin-mediated internalization. J Biol Chem (2013) 288(45):32194-210. doi:10.1074/jbc.M113.503797

49. Förster Y, Schmidt JR, Wissenbach DK, Pfeiffer SE, Baumann S, Hofbauer LC, et al. Microdialysis sampling from wound fluids enables quantitative assessment of cytokines, proteins, and metabolites reveals bone defectspecific molecular profiles. PLoS One (2016) 11:e0159580. doi:10.1371/ journal.pone.0159580

50. Gardner L, Patterson AM, Ashton BA, Stone MA, Middleton J. The human Duffy antigen binds selected inflammatory but not homeostatic chemokines. Biochem Biophys Res Commun (2004) 321:306-12. doi:10.1016/j. bbrc.2004.06.146

51. Wu AC, Morrison NA, Kelly WL, Forwood MR. MCP-1 expression is specifically regulated during activation of skeletal repair and remodeling. Calcif Tissue Int (2013) 92:566-75. doi:10.1007/s00223-013-9718-6

52. Rundle $\mathrm{CH}$, Mohan S, Edderkaoui B. Duffy antigen receptor for chemokines regulates post-fracture inflammation. PLoS One (2013) 8:e77362. doi:10.1371/journal.pone.0077362

53. Ishikawa M, Ito H, Kitaori $\mathrm{T}$, Murata $\mathrm{K}$, Shibuya $\mathrm{H}$, Furu M, et al. MCP/CCR2 signaling is essential for recruitment of mesenchymal progenitor cells during the early phase of fracture healing. PLoS One (2014) 9:e104954. doi:10.1371/ journal.pone.0104954

54. Xing Z, Lu C, Hu D, Yu YY, Wang X, Colnot C, et al. Multiple roles for CCR2 during fracture healing. Dis Model Mech (2010) 3:451-8. doi:10.1242/ dmm.003186

55. Hoff P, Gaber T, Strehl C, Schmidt-Bleek K, Lang A, Huscher D, et al. Immunological characterization of the early human fracture hematoma. Immunol Res (2016) 64(5-6):1195-206. doi:10.1007/s12026-016-8868-9

56. Johnston B, Burns AR, Suematsu M, Issekutz TB, Woodman RC, Kubes P. Chronic inflammation upregulates chemokine receptors and induces neutrophil migration to monocyte chemoattractant protein-1. J Clin Invest (1999) 103(9):1269-76. doi:10.1172/JCI5208

57. Arakaki R, Yamasaki T, Kanno T, Shibasaki N, Sakamoto H, Utsunomiya N, et al. CCL2 as a potential therapeutic target for clear cell renal cell carcinoma. Cancer Med (2016) 10:2920-33. doi:10.1002/cam4.886

58. Wang J, Li H, Li B, Gong Q, Chen X, Wang Q. Co-culture of bone marrow stem cells and macrophages indicates intermediate mechanism between local inflammation and innate immune system in diabetic periodontitis. Exp Ther Med (2016) 12:567-72. doi:10.3892/etm.2016.3386

59. Loyher PL, Rochefort J, Baudesson de Chanville C, Hamon P, Lescaille G, Bertolus $\mathrm{C}$, et al. CCR2 influences $\mathrm{T}$ regulatory cell migration to tumors and serves as a biomarker of cyclophosphamide sensitivity. Cancer Res (2016) 76(22):6483-94. doi:10.1158/0008-5472.CAN-16-0984

60. Glass GE, Chan JK, Freidin A, Feldmann M, Horwood NJ, Nanchahal J. TNF-alpha promotes fracture repair by augmenting the recruitment and differentiation of muscle-derived stromal cells. Proc Natl Acad Sci U S A (2011) 108:1585-90. doi:10.1073/pnas.1018501108

61. Hopwood B, Tsykin A, Findlay DM, Fazzalari NL. Gene expression profile of the bone microenvironment in human fragility fracture bone. Bone (2009) 44(1):87-101. doi:10.1016/j.bone.2008.08.120

62. Liuni FM, Rugiero C, Feola M, Rao C, Pistillo P, Terracciano C, et al. Impaired healing of fragility fractures in type 2 diabetes: clinical and radiographic assessments and serum cytokine levels. Aging Clin Exp Res (2015) 27(Suppl 1):S37-44. doi:10.1007/s40520-015-0422-4

63. Li X, Liu H, Qin L, Tamasi J, Bergenstock M, Shapses S, et al. Determination of dual effects of parathyroid hormone on skeletal gene expression in vivo by microarray and network analysis. J Biol Chem (2007) 282:33086-97. doi:10.1074/jbc.M705194200

64. Jiang X, Sato T, Yao Z, Keeney M, Pajarinen J, Lin TH, et al. Local delivery of mutant CCL2 protein-reduced orthopaedic implant wear particle-induced osteolysis and inflammation in vivo. J Orthop Res (2016) 34:58-64. doi:10.1002/jor.22977

65. Fontaine JL, Hunt NA, Curry S, Kearney T, Jupiter D, Shibuya N, et al. Fracture healing and biomarker expression in a diabetic Zucker rat model. J Am Podiatr Med Assoc (2014) 104:428-33. doi:10.7547/0003-0538-104.5.428

66. Lipes MA, Napolitano M, Jeang KT, Chang NT, Leonard WJ. Identification, cloning, and characterization of an immune activation gene. Proc Natl Acad Sci U S A (1988) 85:9704-8. doi:10.1073/pnas.85.24.9704

67. Alblowi J, Tian C, Siqueira MF, Kayal RA, McKenzie E, Behl Y, et al. Chemokine expression is upregulated in chondrocytes in 
diabetic fracture healing. Bone (2013) 53:294-300. doi:10.1016/j.bone.2012. 12.006

68. Lin F, Xue D, Xie T, Pan Z. HMGB1 promotes cellular chemokine synthesis and potentiates mesenchymal stroma cell migration via Rap1 activation. Mol Med Rep (2016) 14:1283-9. doi:10.3892/mmr.2016.5398

69. Meurer R, Van Riper G, Feeney W, Cunningham P, Hora D, Springer MS. Formation of eosinophilic and monocytic intradermal inflammatory sites in the dog by injection of human RANTES but not human monocyte chemoattractant protein 1, human macrophage inflammatory protein 1a, or human interleukin 8. J Exp Med (1993) 178:1913. doi:10.1084/jem.178.6.1913

70. Schall TJ, Bacon K, Toy KJ, Goeddel DV. Selective attraction of monocytes and T lymphocytes of the memory phenotype by cytokine RANTES. Nature (1990) 347:669. doi:10.1038/347669a0

71. Conti P, Reale M, Barbacane RC, Letourneau R, Theoharides TC. Intramuscular injection of hrRANTES causes mast cell recruitment and increased transcription of histidine decarboxylase in mice: lack of effects in genetically mast cell-deficient W/WV mice. FASEB J (1998) 12:1693-700.

72. Kuna P, Alam R, Ruta U, Gorski P. RANTES induces nasal mucosal inflammation rich in eosinophils, basophils, and lymphocytes in vivo. Am J Respir Crit Care Med (1998) 157:873-9. doi:10.1164/ajrccm.157.3.9610052

73. Combadiere C, Ahuja SK, Van Damme J, Tiffany HL, Gao JL, Murphy PM. Monocyte chemoattractant protein-3 is a functional ligand for CC chemokine receptors 1 and 2B. J Biol Chem (1995) 270:29671-5. doi:10.1074/ jbc.270.50.29671

74. Menten P, Wuyts A, Van Damme J. Monocyte chemotactic protein-3. Eur Cytokine Netw (2001) 12:554-60.

75. Schenk S, Mal N, Finan A, Zhang M, Kiedrowski M, Popovic Z, et al. Monocyte chemotactic protein-3 is a myocardial mesenchymal stem cell homing factor. Stem Cells (2007) 25:245-51. doi:10.1634/stemcells.2006-0293

76. Neunaber C, Oestern S, Andruszkow H, Zeckey C, Mommsen P, Kutter D, et al. Cytokine productive capacity of alveolar macrophages and Kupffer cells after femoral fracture and blunt chest trauma in a murine trauma model. Immunol Lett (2013) 152:159-66. doi:10.1016/j.imlet.2013.05.012

77. Moser B, Loetscher P. Lymphocyte traffic control by chemokines. Nat Immunol (2001) 2:123-8. doi:10.1038/84219

78. Ogilvie P, Bardi G, Clark-Lewis I, Baggiolini M, Uguccioni M. Eotaxin is a natural antagonist for CCR2 and an agonist for CCR5. Blood (2001) 97:1920-4. doi:10.1182/blood.V97.7.1920

79. Luster AD, Jhanwar SC, Chaganti RSK, Kersey JH, Ravetch JV. Interferoninducible gene maps to a chromosomal band associated with a $(4 ; 11)$ translocation in acute leukemia cells. Proc Natl Acad Sci U S A (1978) 84:2868-71. doi:10.1073/pnas.84.9.2868

80. Angiolillo AL, Sgadari C, Taub DD, Liao F, Farber JM, Maheshwari S, et al. Human interferon-inducible protein 10 is a potent inhibitor of angiogenesis in vivo. J Exp Med (1995) 182:155-62. doi:10.1084/jem.182.1.155

81. Sun M, Yang J, Wang J, Hao T, Jiang D, Bao G, et al. TNF- $\alpha$ is upregulated in T2DM patients with fracture and promotes the apoptosis of osteoblast cells in vitro in the presence of high glucose. Cytokine (2016) 80:35-42. doi:10.1016/j.cyto.2016.01.011

82. Baggiolini M, Dewald B, Moser B. Interleukin-8 and related chemotactic cytokines - CXC and CC chemokines. Adv Immunol (1994) 55:97-179. doi:10.1016/S0065-2776(08)60509-X

83. Baggiolini M, Dewald B, Moser B. Human chemokines: an update. Annu Rev Immunol (1997) 15:675-705. doi:10.1146/annurev.immunol.15.1.675

84. Pruijt JF, van Kooyk Y, Figdor CG, Lindley IJ, Willemze R, Fibbe WE. AntiLFA-1 blocking antibodies prevent mobilization of hematopoietic progenitor cells induced by interleukin-8. Blood (1998) 91:4099-105.

85. Bleul CC, Farzan M, Choe H, Parolin C, Clark-Lewis I, Sodroski J, et al. The lymphocyte chemoattractant SDF-1 is a ligand for LESTR/fusin and blocks HIV-1 entry. Nature (1996) 382:829-33. doi:10.1038/382829a0

86. Oberlin E, Amara A, Bachelerie F, Bessia C, Virelizier J-L, ArenzanaSeisdedos F, et al. The CXC chemokine SDF-1 is the ligand for LESTR/ fusin and prevents infection by T-cell-line-adapted HIV-1. Nature (1996) 382:833-5. Erratum in: Nature (1996) 384:288 only. doi:10.1038/382833a0
87. Carr AN, Howard BW, Yang HT, Eby-Wilkens E, Loos P, Varbanov A, et al. Efficacy of systemic administration of SDF-1 in a model of vascular insufficiency: support for an endothelium-dependent mechanism. Cardiovasc Res (2006) 69:925-35. doi:10.1016/j.cardiores.2005.12.005

88. Yamaguchi J, Kusano KF, Masuo O, Kawamoto A, Silver M, Murasawa S, et al. Stromal cell-derived factor-1 effects on ex vivo expanded endothelial progenitor cell recruitment for ischemic neovascularization. Circulation (2003) 107:1322-8. doi:10.1161/01.CIR.0000055313.77510.22

89. Myers TJ, Longobardi L, Willcockson H, Temple JD, Tagliafierro L, Ye P, et al. BMP2 regulation of CXCL12 cellular, temporal, and spatial expression is essential during fracture repair. JBone Miner Res (2015) 30:2014-27. doi: $10.1002 / j b m r .2548$

90. Kitaori T, Ito H, Schwarz EM, Tsutsumi R, Yoshitomi H, Oishi S, et al. Stromal cell-derived factor 1/CXCR4 signaling is critical for the recruitment of mesenchymal stem cells to the fracture site during skeletal repair in a mouse model. Arthritis Rheum (2009) 60:813-23. doi:10.1002/art.24330

91. Toupadakis CA, Wong A, Genetos DC, Chung DJ, Murugesh D, Anderson MJ, et al. Long-term administration of AMD3100, an antagonist of SDF-1/ CXCR4 signaling, alters fracture repair. JOrthop Res (2012) 30:1853-9. doi:10.1002/jor.22145

92. Ceradini D, Kulkarni A, Callaghan M, Tepper O, Bastidas N, Kleinman M, et al. Progenitor cell trafficking is regulated by hypoxic gradients through HIF-1 induction of SDF-1. Nat Med (2004) 10:858-64. doi:10.1038/nm1075

93. Einhorn TA. The cell and molecular biology of fracture healing. Clin Orthop Relat Res (1998) (355 Suppl):S7-21. doi:10.1097/00003086-199810001-00003

94. Kumar V, Abbas AK, Fausto N. Robbins \& Cotran Pathologic Basis of Disease: International. 7th ed. New York: Elsevier (2005).

95. Johnson Z, Power CA, Weiss C, Rintelen F, Ji H, Ruckle T, et al. Chemokine inhibition-why, when, where, which and how? Biochem Soc Trans (2004) 32(Pt2):366-77. doi:10.1042/bst0320366

96. Sordi V, Malosio ML, Marchesi F, Mercalli A, Melzi R, Giordano T, et al. Bone marrow mesenchymal stem cells express a restricted set of functionally active chemokine receptors capable of promoting migration to pancreatic islets. Blood (2005) 106:419-27. doi:10.1182/blood-2004-09-3507

97. Ponte AL, Marais E, Gallay N, Langonné A, Delorme B, Hérault O, et al. The in vitro migration capacity of human bone marrow mesenchymal stem cells: comparison of chemokine and growth factor chemotactic activities. Stem Cells (2007) 25:1737-45. doi:10.1634/stemcells.2007-0054

98. Rice CM, Scolding NJ. Adult human mesenchymal cells proliferate and migrate in response to chemokines expressed in demyelination. Cell Adh Migr (2010) 4:235-40. doi:10.4161/cam.4.2.11404

99. Rapp AE, Bindl R, Heilmann A, Erbacher A, Müller I, Brenner RE, et al. Systemic mesenchymal stem cell administration enhances bone formation in fracture repair but not load-induced bone formation. Eur Cell Mater (2015) 29:22-34. doi:10.22203/eCM.v029a02

100. Hosogane N, Huang Z, Rawlins BA, Liu X, Boachie-Adjei O, Boskey AL, et al. Stromal derived factor-1 regulates bone morphogenetic protein 2-induced osteogenic differentiation of primary mesenchymal stem cells. Int J Biochem Cell Biol (2010) 42:1132-41. doi:10.1016/j.biocel.2010.03.020

101. Zhu W, Liang G, Huang Z, Doty SB, Boskey AL. Conditional inactivation of the CXCR4 receptor in osteoprecursors reduces postnatal bone formation due to impaired osteoblast development. J Biol Chem (2011) 286:26794-805. doi:10.1074/jbc.M111.250985

Conflict of Interest Statement: The author declares that the research was conducted in the absence of any commercial or financial relationships that could be construed as a potential conflict of interest.

Copyright $\odot 2017$ Edderkaoui. This is an open-access article distributed under the terms of the Creative Commons Attribution License (CC BY). The use, distribution or reproduction in other forums is permitted, provided the original author(s) or licensor are credited and that the original publication in this journal is cited, in accordance with accepted academic practice. No use, distribution or reproduction is permitted which does not comply with these terms. 